\title{
GCU
}

Glasgow Caledonian

University

University for the Common Good

\section{Implementation of eco-engineering design into existing slope stability design practices}

Tardio, Guillermo; Mickovski, Slobodan B.

Published in:

Ecological Engineering

DOI:

10.1016/j.ecoleng.2016.03.036

Publication date:

2016

Document Version

Author accepted manuscript

Link to publication in ResearchOnline

Citation for published version (Harvard):

Tardio, G \& Mickovski, SB 2016, 'Implementation of eco-engineering design into existing slope stability design practices', Ecological Engineering, vol. 92, pp. 138-147. https://doi.org/10.1016/j.ecoleng.2016.03.036

\section{General rights}

Copyright and moral rights for the publications made accessible in the public portal are retained by the authors and/or other copyright owners and it is a condition of accessing publications that users recognise and abide by the legal requirements associated with these rights.

Take down policy

If you believe that this document breaches copyright please view our takedown policy at https://edshare.gcu.ac.uk/id/eprint/5179 for details of how to contact us. 


\title{
Implementation of eco-engineering design into existing slope stability design practices
}

Guillermo Tardío a, ${ }^{\text {, }}$ Slobodan B. Mickovski ${ }^{\mathrm{b}}$

a Technical University of Madrid. Avenida Niceto Alcalá Zamora, 6, 4D. 28905 Getafe (Madrid). Spain. Tel: ++34 9117283 60, e-mail: gtarcer@gmail.com

b School of Engineering and Built Environment, Glasgow Caledonian University, 70 Cowcaddens Rd, G4 OBA, Glasgow, Scotland, UK. Tel: ++44 141 2731105, e-mail: Slobodan.mickovski@gcu.ac.uk

* Corresponding author

\begin{abstract}
Eco-engineering techniques involve the use of both plants and inert materials where, in the latter, non-treated wood is usually present. The two different elements will both evolve with time and change their mechanical properties differently. On one hand, the wood will degrade decreasing its effective cross sectional area with time. On the other hand, the live plant material will grow and propagate new roots as time progresses. Both root development and inert material changes must be accounted for in order to realistically simulate a bioengineered slope evolution and design effective eco-engineering solutions.

The dynamic nature of a bioengineered work sets different scenarios throughout the slope design life. All these different stages must be taken into account in the work design process. In this work, we propose an adaptation of the existing routines and procedures of both geotechnical practice and civil engineering design scheme in order to closely reflect the inclusion of bioengineering methods in the classic geotechnical
\end{abstract}


engineering problems. A design methodology covering different critical points within the lifecycle of a bioengineered slope is proposed and put into practice into the design stage for a case study in Scotland. By detecting critical points at the design stage the proposed methodology was proven to offer an improved eco-engineering work design scheme. With the use of the proposed method both external and internal stability checks with their corresponding safety factor values increase with time and there are no conflicts between the two evolving processes involved in this kind of works.

Keywords: bioengineered slope, reinforced slope, roots, slope stability, soil reinforcement, wood decay, durability

\section{Introduction}

Ground bio-engineering, also termed eco-engineering, is the use of living plants or cut plant material, either alone or in combination with inert structures, to control soil erosion and the mass movement of land in order to fulfil engineering functions (Schiechtl, 1988). The self-repairing characteristics of the vegetation used, and the resilience capacity of the bioengineered area (Mickovski, 2014) are very important allies in the eco-engineering design philosophy.

The eco-engineering solutions have inherent advantages over classic civil engineering solutions with respect to economy, ease of construction, low landscape impact and opportunities for incorporation of vegetation or plantings within the structure (Gray and Sotir, 1996). One of the main design disadvantages are related to this latter issue since the use of both living and inert biological materials (e.g. wood) involves incorporating temporary variable elements in terms of design and performance reliability of the eco-engineering works (Stokes et al., 2014). The eco-engineering philosophy follows the sustainability idea of design with readily available materials on or adjacent to the site which involves the use of materials such as wood or rocks. The 
use of wood coming from nearby silvicultural treatments (Coppin and Richards, 1990) entails the use of materials with a wide variety of properties (young and mature wood) from different species.

The eco-engineering solutions provide a combination of the benefits of immediate protection against soil instability and the long-term stabilisation due to the reinforcement effect of the roots on the soil. As with any stabilization technique, there is a stress (or load) transfer between the soil and the structure but, in contrast to other solutions, this initial response is substituted by an evolving role of the living material used in the eco-engineering work as the time progresses. Once the plants become established, the subsequent vegetation gradually takes on more of the structural function of the inert members (Gray and Sotir, 1996). The way roots reinforce soil can be explained by both mechanical and hydrological effects. From the former perspective, roots can bind the soil together and contribute to both a higher soil bearing capacity and shear strength (Willatt and Sulistyaningsih, 1990) whereas, from the latter, they can decrease the soil pore water pressures and, therefore, soil effective stresses (Terzaghi's principle; Lambe and Whitman, 1979) thus improving the slope stability.

Over the past eighty years, extensive engineering and research studies have provided a sound set of soil mechanical principles and analytical procedures for slope stabilization (Terzaghi, 1936; Sowers, 1979; Duncan and Wright, 2005). An improved understanding of the changes in soil properties that can occur over time is one of the most important developments of slope stability design schemes. The presence of other material in the soil (including plant roots) changes the properties of the continuum and, if these changes can be predicted, the engineers can choose the best additions for stability. The recognition of the requirements and limitations for the use of non-inert (live) material in slope stability design standards would usher in a more mature phase of the use of ecotechnological solutions for soil stabilisation purposes. 
With bioengineered slopes, the nature of the materials used generates a natural evolving dynamic into the slope design life. One of the most important changes in the soil conditions takes place when plants, the live components, begin to grow and propagate new roots (Bischetti et al., 2009). Besides, the wood, one of the inert components used in eco-engineering techniques, is generally not treated and, as a consequence of this, its mechanical properties deteriorate as time progresses (Leicester et al., 2003). Therefore, for bioengineering slope design the time and elements durability must be considered more explicitly throughout the design life of the slope.

The existing structural timber design standards (e.g. EN 1995-11:2004/A1:2008 Eurocode 5) provide a regulatory framework for eco-engineering work design. Similarly, the existing structural/geotechnical design procedures for slope stabilisation solutions (e.g. manufacturers standard designs, trade associations standard designs, state and federal agencies, Eurocode 7, etc.) do not accommodate the particularities derived from the dynamic and changing nature of the ecoengineering solutions. However, the eco-engineering design is more complex due to both the presence of different materials and the need to take into account the combination and integration of the particularities of the wooden elements used for specific eco-engineering works (e.g. wood decay rate, wood natural durability and the use of small diameter round wood) with the live materials used. Furthermore, the ground bioengineering techniques are designed according to soil stabilization or geotechnical design general methodologies (Coppin and Richards, 1990; Menegazzi and Palmeri, 2013) and they do not have a standardised specific approach as it is the case with other traditional stabilisation techniques. To the best of our knowledge, the engineering approach comprising a sequence of stages reflecting the design life stages and associated changes in the eco-engineering structure has not yet been applied to eco-engineering design. 
To cover the apparent gap in the design with vegetation for stability (Stokes et al., 2014), there is a need for a clear methodology, based on existing structural/geotechnical design procedures, to put the eco-engineering solution design into practice and justify its application from sustainability, resilience and stability point of view (Mickovski, 2014). The aim of this paper is to use the existing engineering approach and attempt incorporating both wood deterioration and live plant processes and effects within a temporal framework. To achieve this, our objectives are to integrate the stress transfer process between the inert elements and the vegetation, as well to incorporate both the typical dynamic nature and the evolution of an ecoengineering work into eco-engineering design methodologies, demonstrated on a real life case study.

\section{Materials and methods}

\subsection{Background}

In designing and constructing new earthwork slopes, it is important to attempt to anticipate the relevant changes in properties and conditions that may affect them during the design, ensuring that the stability is not compromised by any foreseeable change (Duncan and Wright, 2005). In the case of bio-engineered slopes, one of the major changes in the long term is the growth and development of the plants used in conjunction with inert materials. Additionally, the changes in the loads or stresses acting on the slope will result in changes in the stability of the slopes. Therefore, it is often necessary to perform stability analyses corresponding to several different scenarios, reflecting different stages in the life of a slope. This is a well established principle in the standard slope stability design (Duncan and Wright, 2005; EN 1997 Eurocode 7), and it should be applied to bioengineered slopes because a changing scenario during the slope design life is in the very core of the ecotechnological solution design and philosophy. The two main elements involving changes in an eco- 
engineering technique stability checks during the slope design life are the wooden elements and the plants. While wooden elements will degrade with time, the plants' roots will develop and grow.

\subsubsection{Wood durability}

The inherent ability of wood species to resist biological deterioration is referred to as natural durability or decay resistance (Eaton and Hale, 1993; Johnson et al., 2006). Natural durability varies between wood species (e.g. State Forests of New South Wales, 1995) and is explained mainly by the composition and amount of wood extractives (Eaton and Hale, 1993). Generally, sapwood is the least durable wood part (Figure 1), while heartwood cannot be treated and therefore its durability is dictated by its natural durability class (State Forests of New South Wales, 1995). Knowledge about natural durability is obtained by field and laboratory tests (e.g. Princes Risborough Laboratory, 1976; Leicester et al., 2003) as well as by practical experience of the end users (Willeitner and Peek, 1997).

a)

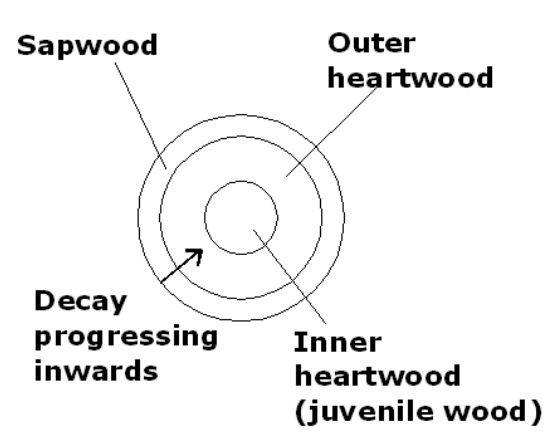

b)

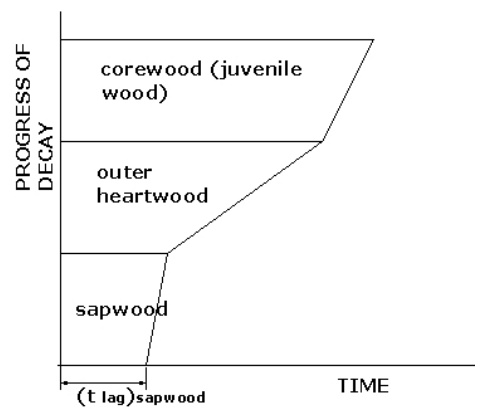

Figure 1 a) Wood parts, b) deterioration rates for the different wood parts (adapted from Leicester et al. (2003)

The existing models for simulating wood deterioration processes (e.g. Scheffer, 1971; Leicester et al., 2003), idealise the process to be bi-linear (Leicester et al., 2003) (Figure 2) where the untreated wood in the ground would steadily decay along the perimeter after a time lag of decay. The rate of decay ( $\mathrm{mm} / \mathrm{year}$ ) can be calculated as: 
While $\mathrm{K}_{\text {climate }}$ depends on mean precipitation value, mean annual temperature and the number of dry months on the site (see Leicester et al., 2003), $\mathrm{K}_{\text {wood }}$ depends on the type of wood (Leicester et al., 2003).

The lag time (years) for the sapwood (which is the wood with the least durability and would decay first; Fig. 1) can be estimated in terms of the sapwood decay rate ( $\left.r_{\text {sapwood }}\right)$ as shown in Eq. 2 (Wang et al., 2007):

$$
t_{\text {lag_sapwood }}=5.5 \cdot r_{\text {sapwood }}^{-0.95}
$$

According to the preceding model the decay progresses inwards while the remaining wood keeps the initial mechanical properties. Therefore, if at a time the decay depth is $d_{t}(\mathrm{~mm})$ (Fig. 2), the bending strength can be calculated as (Wang et al., 2007):

$$
R=\frac{\pi}{32}\left(D-2 d_{t}\right)^{3} f_{d}
$$

Where $D$ is the initial diameter $(\mathrm{mm})$ and $f_{d}$ is the design strength value which is calculated by using both characteristic strength values and structural design standards (e.g. EN 1995-1-1:2004/A1:2008 Eurocode 5). Characteristic strength values of undecayed wood can be found in the literature or measured in the laboratory (de Vries, 1998; Ranta-Maunus et al., 1998).

In a wooden element, the service life is assumed to be the time at which its residual strength decreases to $70 \%$ of its original strength (Wang et al., 2007). For the case of a circular wooden element of initial diameter $D(\mathrm{~mm})$ subjected to bending, the decay depth $(\mathrm{mm})$ at service life, $d_{L}$ (years), is (Leicester et al., 2003):

$$
d_{L}=\frac{1}{2}\left(1-0.7^{1 / 3}\right) \cdot D
$$

Then, the service life $L$ (years) (see Fig. 2) is estimated taking into account either the decay lag ( $\mathrm{t}_{\mathrm{lag}}$, Eq. 2) or the decay rate (r, Eq. 1) as shown in Eq. 5. 


$$
L=t_{\text {lag }}+\frac{d_{L}}{r}
$$

a)

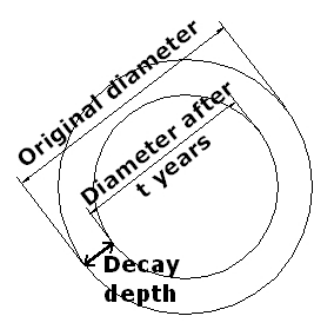

b)

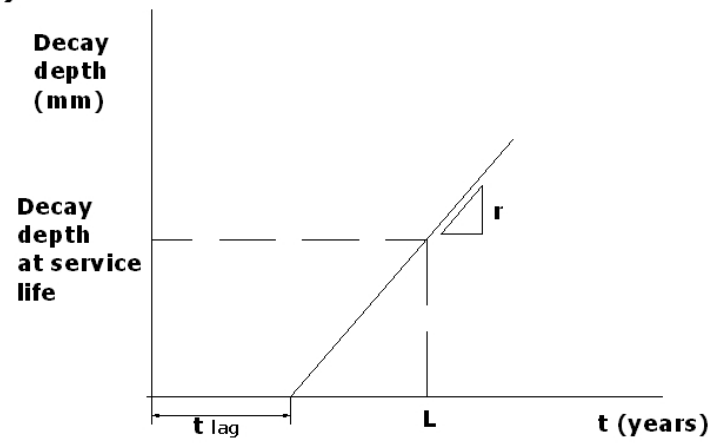

Figure 2 a) Diameter variation and decay depth $\left.\left(d_{t}\right), b\right)$ idealised progress of decay depth with time (adapted from Leicester et al., 2003). $t_{\text {lag }}$ (lag time) and $L$ (service life) are shown.

Apart from the decay effects, the physical and mechanical properties (density, strength, elasticity; Simpson and Wang, 2001) of wood are affected by its moisture content (MC) because of its hygroscopic nature. The wood exchanges its moisture content $(\mathrm{MC})$ with the outer atmosphere until equilibrium moisture content (EMC) is achieved. Generally, this occurs in the course of the first year of exposure (Forest Products Laboratory, 1999). EMC values vary with both relative atmospheric humidity and temperature (Forest Products Laboratory, 1999). In wood structure calculation standards both physical and mechanical properties refer to $12 \%$ moisture content (MC). As the in situ wood would have different MC, in order to calculate the density of such wood at EMC, a $0.5 \%$ adjustment is made for every percentage point difference in moisture content between EMC and MC (EN 384:2010).

\subsubsection{Plants}

Plants have both beneficial and adverse effects on slope stability and are the most variable element in an eco-engineering intervention. The way in which vegetation enhances mass stability is both via root reinforcement and via soil moisture depletion. Mechanical effects of vegetation on slope stability have been extensively documented 
overtime (e.g. Wu et al., 1979; Norris et al., 2008; Stokes et al., 2014). Among the main adverse effects of vegetation are the windthrow and the surcharge because of the vegetation weight. Models related to either plant growth or root distribution with depth are very useful for incorporating new effects in eco-engineering techniques design because roots take the loads and distribute into soil. Small vegetation roots reinforce the soil providing and added cohesion value (Waldron, 1977) which can be included in the Mohr-Coulomb constitutive equation (Wu et al., 1979; Ekanayake and Phillips, 2002; Stokes et al., 2008) for soil strength.

Under field conditions, roots occur in different sizes and lengths and can have different tensile strengths and degrees of fixity. Accordingly, two failure mechanisms are predominant in a deforming rooted soil: root tensile break mode and root pull-out mode (Waldron and Dakessian, 1981). For preliminary assessment of vegetation reinforcement, a simple breakage model (perpendicular reinforcement model; Wu et al., 1979) can be used assuming all roots break in tension under load. This should be used with caution because of its simplicity, reduced amount of input parameters (Root Area Ratio at depth $z-\operatorname{RAR}(z)$ and root tensile strength Tr; Eq. 6) and observed realistic application (Mickovski et al., 2008). It must be borne in mind that only small roots (diameter $<10 \mathrm{~mm}$ ) are considered in this model to compute the added cohesion value $\left(c_{r}\right)$, since big roots only contribute to slope stability as structural anchorage (Mickovski et al., 2009).

$$
c_{r}=1.2 \cdot R A R(z) \cdot T_{r}
$$

Eq. 6

Root pullout mechanism depends on the root anchorage length, soil type, root physical properties and root system architecture. When a root is not long enough it will tend to slip or pull-out when the soil-root composite is sheared. Assessing the pull-out resistance for quantification of root reinforcement has been analysed by several authors (Norris, 2005; Mickovski et al., 2005). Vertical uprooting of whole plants has 
been also used to determine the contribution of a root system to soil fixation (Norris, 2005). Lateral plant uprooting (or overturning) has been investigated by winch experiments (e.g. Crook and Ennos, 1996; Coutts et al., 1998; Mickovski and Ennos, 2002; Mickovski and Ennos, 2003; Cucchi et al., 2004; Stokes et al., 2007).

Root system morphology and properties can be studied by field techniques (e.g. Böhm, 1979; Van Noordwijk et al., 2000) or indirectly estimated from theoretical root distribution models (Laio et al., 2006; Preti et al., 2010) that only need readily available long-term climatic and pedological parameters and a species-specific scaling factor. Published literature (e.g. Francis et al., 2005; Schenk and Jackson, 2002; Waisel et al., 2002) includes data of root systems of the most common living material used in ecotechnological solutions.

\subsubsection{External and internal stability}

As with any stabilization structure, eco-engineering solutions must be checked from a structural point of view to ensure that the external (sliding, overturning, bearing capacity and slope failure; Fig. 3) and internal stability are satisfactory and these checks must include both decay and plant effects in order to reflect the changes during the lifetime of the eco-engineered solution. In the case of wooden elements, the internal stability calculation is based on the governing timber structural design (EN 1995-1-1:2004/A1:2008 Eurocode 5). On the other hand, the external stability checks are usually performed in line with existing geotechnical engineering design standards and the stability is expressed in terms of a Factor of Safety (FoS; e.g. Tardio and Mickovski, 2015). In this study, we have adopted the FoS expressions for bare and vegetated soil (Gray and Sotir, 1996) and use lumped global FoS for the sliding and overturning checks since the purpose on this paper is to show how the different stability checks vary with time. The resistance to sliding $\left(\mathrm{FoS}_{\mathrm{s}}\right)$ will be affected by evolution of the RAR value with time across the sliding plane (Preti and Cantini, 2002) while the resistance to overturning $\left(\mathrm{FoS}_{\mathrm{o}}\right)$ will be affected by the pull out force evolution with time due to root 
growth (Figure 3). The global stability of eco-engineered slope can then be assessed using existing slope stability analysis methods (Duncan and Wright, 2005) taking into account both long term (drained) and short term (undrained) scenarios.

A)

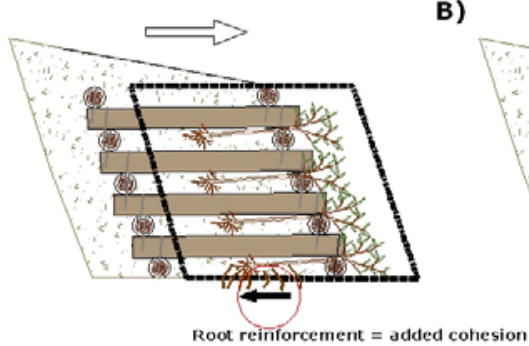

)

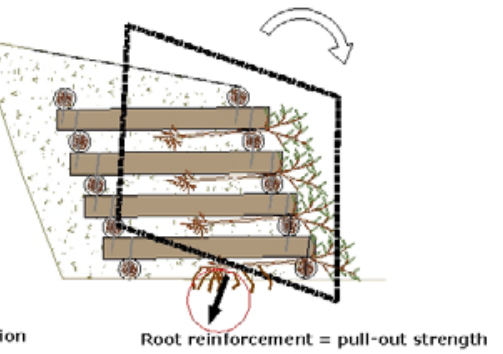

c)

overall FAILURE (sLope FAILURE)

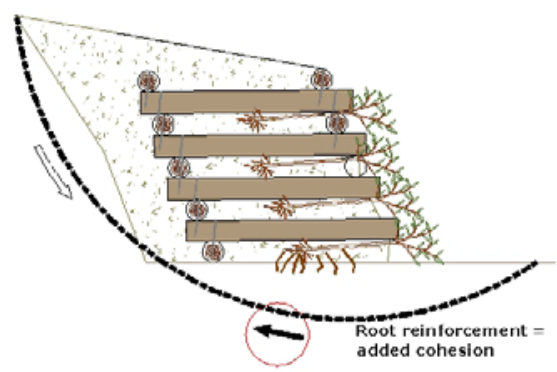

Figure 3 A) Sliding check, B) overturning check, C) slope failure check. The roots effect (if applicable) is highlighted in a circle

\subsection{Approach and methodology}

In order to include the variation of strength in both living and inert components of the eco-engineering solution and assess its effect on the stability of the system with time (Gray and Sotir, 1996), monitoring and adaptation of the stability check methodology are required. Based on durability considerations, the eco-engineered slope design must include at least two stages: before the plants have propagated roots (traditional/standard design of stabilization projects) and after the propagation of new roots which affect the soil mechanical properties (newly proposed methodology). Within the latter, intermediate scenarios making allowance for the stress transfer phenomena between the wood or inert material and the plants should be considered before the last scenario where living plants are considered to be the major source of the overall 
system stability. In this latter case, the wooden materials accompanying the plants would have already fully decayed or are considered ineffective for stabilization purposes. This new proposed methodology fits well within the generic geotechnical design framework where several stages or design situations must be analysed over time (EN 1997 - Eurocode 7: Geotechnical design) and the analysis of the structure at different time stages incorporates different values of the variables involved (e.g. decay depth, mechanical strengths, root evolution/reinforcement, etc.).

When using untreated wood elements, the decay process evolution can be introduced in the design stages through the service life concept (L, Eq. 5) used as a basis for the definition of design stages. The service life of the inert materials used must ensure a suitable development of the living material in order to make feasible the stabilising effect transfer process. Therefore, the effective role of the inert material used must provide a service life in terms of their stabilising effects of at least several years, because all elements interact to affect the overall safety factor of the system over time (Gray and Leiser, 1982). On the other hand, small and medium sized (100-250 mm diameter) round wood used in eco-engineering works (e.g. log crib walls or live slope grating; Zeh, 2007) is the main structural material with known properties (de Vries, 1998; Ranta-Maunus et al., 1998; Boren, 1999) but has higher decay rate values because of the high proportion of sapwood (Zobel and Sprague, 1998).

In the methodological approach proposed in this paper (Figure 4) the service life of the structural wooden elements is assumed to set the threshold after which there is no interaction/synergy between the living plants and the wooden elements as stabilising factors. From this threshold on, the vegetation will play the major role in keeping the system stable and the structural effects of the wooden elements should be neglected in stability checks in line with the main philosophy of the ecotechnological approach which should take advantage of the dynamic of the living systems (Gray and Sotir, 1996). 
A set of different scenarios (stages) is defined in order to cover the ecoengineering work evolution with time (Figure 4). For the short term (undrained, end of construction stage) check the plant effects will be not be included due to a lack of time for plant establishment after construction. For the drained (long term) checks, different scenarios will be taken into consideration. First, a scenario representing the stage throughout the first growth season of the eco-engineering work in which the plant effects are not included yet. After this stage, depending on whether wooden elements are present in the work or not, more design scenarios are defined. Without wooden elements being used, an additional stage that includes full plant effects will be necessary to depict the overall evolution of the eco-engineering work from a design point of view. Where wooden elements are being used, several additional stages will be defined depending on the wood service life $(\mathrm{L})$ value calculated according to Eq. 5 .

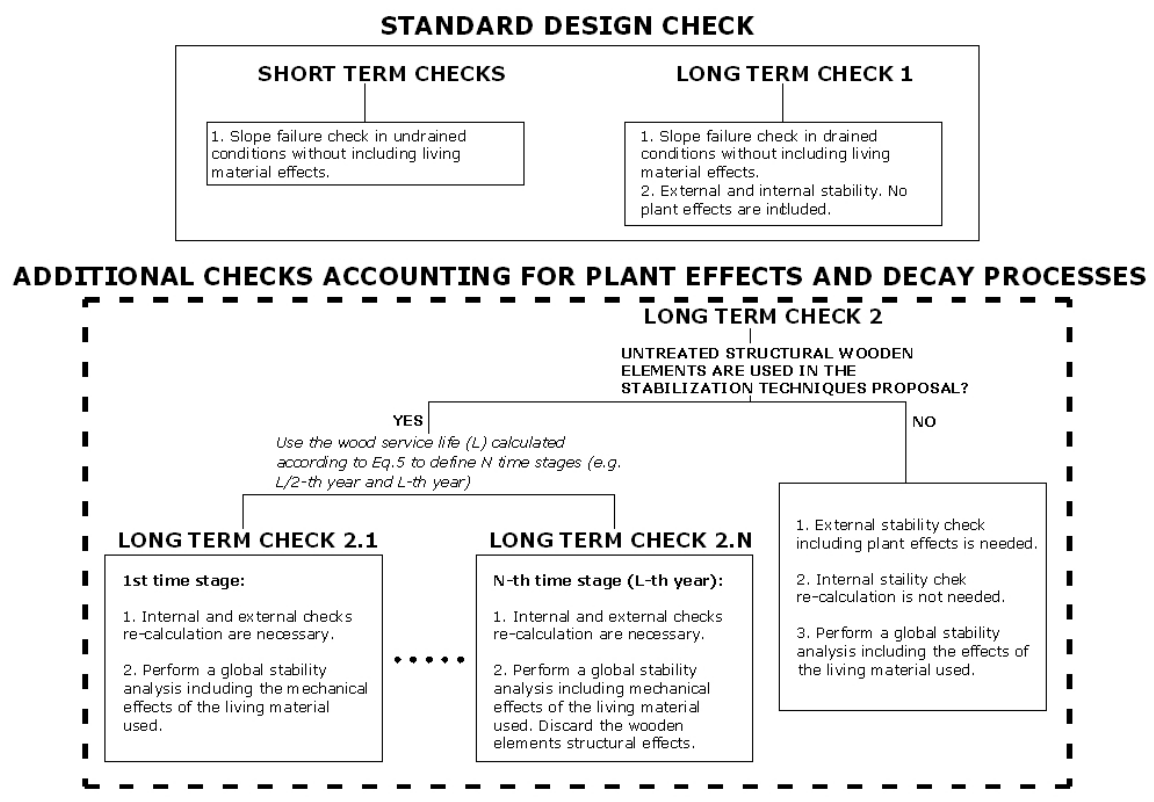

Figure 4 Flowchart of the methodology; adapted from FHWA-NHI-00-43 (2001). The novel approach stages are shown as additional checks within the dashed line area.

\subsection{Methodology validation - case study}

2.3.1. Site characteristics 
The study site lies on Catterline Bay, Northeastern Scotland, UK (x: 387100 $\mathrm{y}: 778350)$, located in a region with a mean annual temperature of $8.02^{\circ} \mathrm{C}$, a mean annual rainfall of $1232 \mathrm{~mm}$, no (rainfall $<5 \mathrm{~mm}$ ) dry months per year (UK Met Office) which constitutes a humid temperate climate (Cfc: subpolar oceanic climate: Köppen, 1884). The precipitation is characterised by frequent, low intensity rainfall events, seldom heavy storms, and Kclimate $=1.56$ (Leicester et al., 2003).

The topography of the study site is dominated by sloped terrain (slope angle 2550 degrees) and cliffs. Published geological maps (BGS, 2013) show the superficial soils at the site area to comprise Raised Beach Deposits (RBD) of sands and gravels of the Quaternary period on the slopes and Mill of Forest Till Formation (Glacial Till) at the crest of the slope. A more detailed geological characterisation of the site can be found in Mickovski et al (2015). Shallow and well drained soils are found within the study area resting on top of sedimentary bedrock (i.e. conglomerate and sandstone). The soils comprise mainly silty sands with high organic matter content, soil porosity, and good drainage conditions (Mickovski et al., 2015).

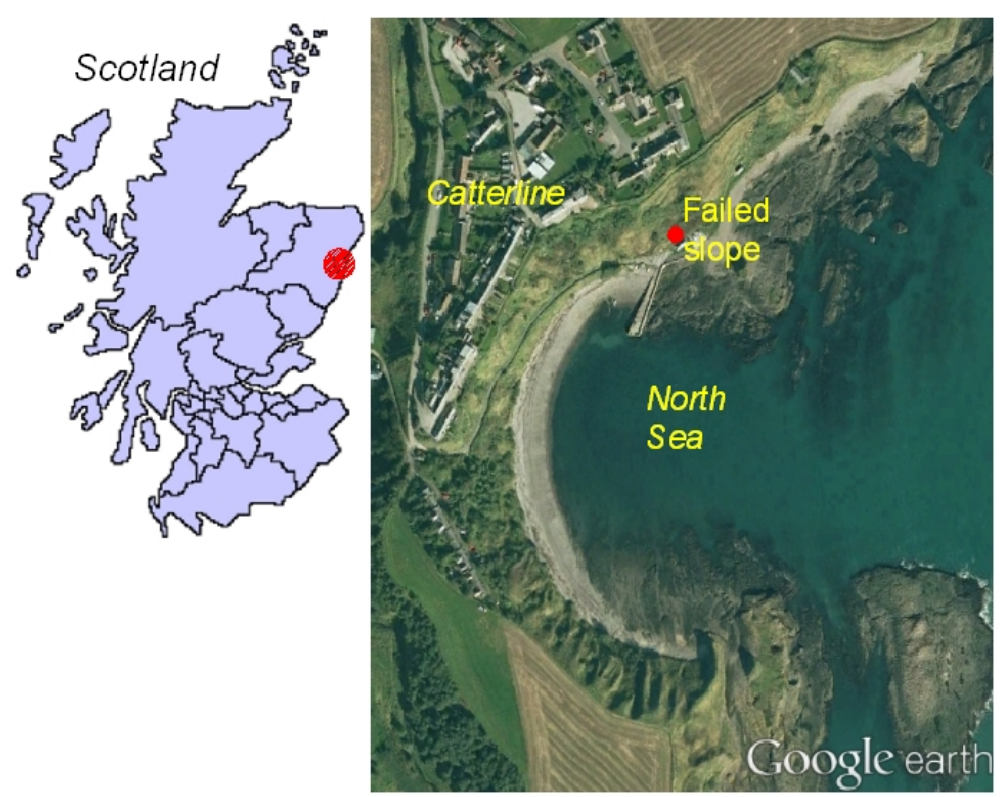

Figure 5 Study site (Google Earth image @ 2016 Getmapping plc) 
The vegetation cover is dominated by herbaceous weeds and grasses, riparian tress and agricultural crops of wheat and barley. Typical perennial pioneer herbs that are well distributed over the site are Erigeron acris L., Rumex obtusifolius L. and Silene dioica Clariv. The main tree species in the area are Fraxinus excelsior L., Acer pseudoplatanus L., Salix viminalis L. and Salix caprea L. Pinus sylvestris L. is present in small stands within the site.

Different slope instability episodes have been reported in the past (e.g. Kincardineshire Observer 11/4/2013; Mickovski et al., 2015) mainly associated to heavy rainfall events (Fig. 6). A comprehensive analysis of the different slope failure types in the study site can be found in Mickovski et al (2015). Particularly, deep seated failures were detected at the toe of the coastal slope and, in order to mitigate against these instabilities, a log crib wall will be designed.

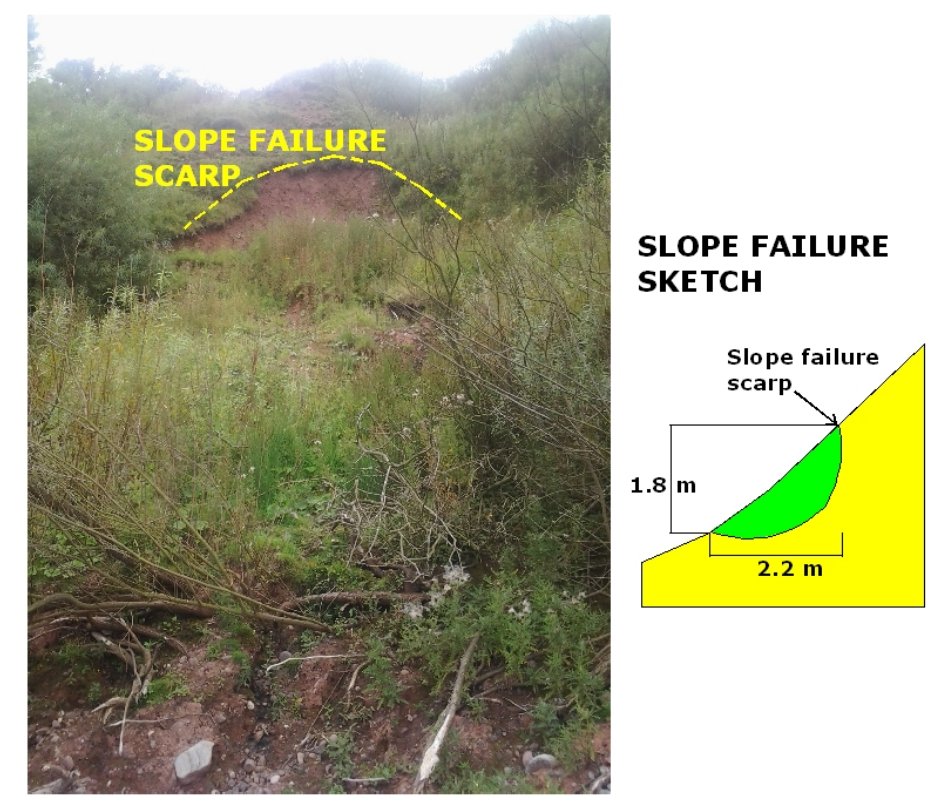

Figure 6 Slope failure in the study site

\subsubsection{Material characteristics}

Given the type and permeability of the soil, i.e. silty sands, only drained conditions will be taken into account. The soil strength properties obtained through a standard laboratory shearbox test (Gonzalez-Ollauri, unpublished data) showed an 
effective cohesion of $7 \mathrm{KPa}$, and effective angle of internal friction of $30^{\circ}$. The soil unit weight was $20.10 \mathrm{kN} / \mathrm{m}^{3}$ (González-Ollauri and Mickovski, 2014).

It is assumed that the wood for the eco-engineering structure will come from the nearby Scots pine (Pinus sylvestris L.) stands following the sustainable design philosophy, with logs of approx. $200 \mathrm{~mm}$ diameter and characteristic bending strength of $20 \mathrm{~N} / \mathrm{mm}^{2}$ (C20 class; Moore et al., 2008) made available for the work. Scots pine corewood is moderately resistant (durability class 3; AS 5604-2005) which yields $\mathrm{K}_{\text {wood }}$ $=1.30$ (Eq.1; Leicester et al., 2003). Scots pine sapwood has a $K_{\text {wood }}$ equal to 5.44 (Eq.1; Leicester et al., 2003).

For a Service class 3 and permanent loads the modification factor $k_{\bmod }=0.5$ (EN 1995-1-1:2004/A1:2008 Eurocode 5). The material coefficient $g_{m}=1.3$ and, thus, the design bending strength will be equal to $7.69 \mathrm{~N} / \mathrm{mm}^{2}$. The wood density interpolation shows a density of $525.25 \mathrm{Kg} / \mathrm{m}^{3}$ for the $\mathrm{EMC}=21 \%$ characteristic for Scots pine (EN 384:2010).

The living material will consist of 1.80 m length Goat willow (Salix caprea L.) living branches (approx. diameter $10 \mathrm{~mm}$ ) harvested from the site. To investigate the rooting characteristics of goat willow, root pullout tests were performed on site in accordance with existing methodology (Mickovski et al., 2005) on five different plants of different age, matching the service life analysis (3x3-year-old plants, 2x6-year-old plants). Root characterisation and distribution with depth was performed both in situ and in the laboratory according to Böhm (1979). 50 root samples with diameters ranging between $0.64 \mathrm{~mm}$ and $4.63 \mathrm{~mm}$ were tested in tension using a universal testing machine while measuring the force at constant displacement rate of $5 \mathrm{~mm} / \mathrm{min}$ which mimicked the potential failure velocity. Only specimens that fractured in the middle third of the sample were used in further analysis since rupture near the grips might be influenced by higher stress concentration or structural damage. The results of 
the root tensile tests were used to calculate the root tensile strength at the moment of maximum tensile force applied.

\subsubsection{Proposed solution description and remarks}

After analysing the topography on site it was decided to design a log crib wall with $1.8 \mathrm{~m}$ height, $1.8 \mathrm{~m}$ width and $5.0 \mathrm{~m}$ length (see Figure 6) - dimensions reflecting the size of the recent failure at the toe of the slope. The slope of the backfill was designed to be $30^{\circ}$ and to match the surrounding terrain. Three goat willow living branches per meter will be used in every log row (see Figure 7; Schiechtl, 1988; Gray and Sotir, 1996).

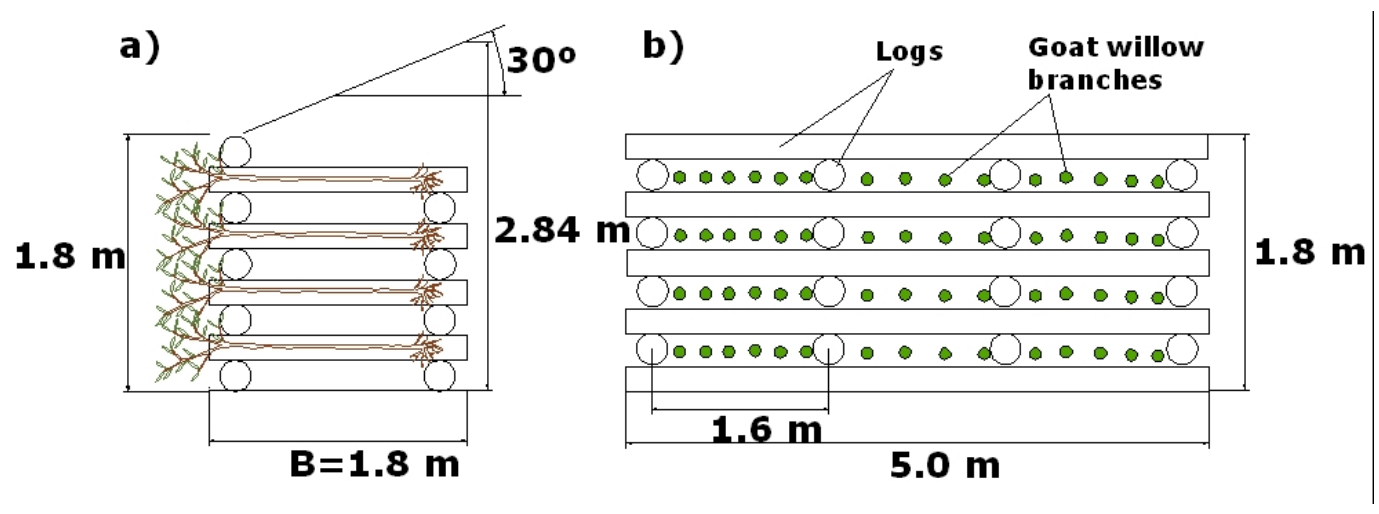

Figure 7 Log crib wall geometry a) cross-section, b) front-view

The internal stability check was performed for the 'in-ground condition' - critical situation where the wooden elements (logs) are buried (Figure 8). For the internal stability check, the bending strength analyses were performed according to Eurocode 5 (EN 1995-1-1:2004/A1:2008). The outer log row is considered the most critical from both durability and bending stress aspect (Stangl and Tesarz, 2003). The inner row of logs will be subjected to both a lower temperature and moisture variation throughout the year and at that depth the level of oxygen will be lower and therefore, the biotic activity will be lower (Stangl and Tesarz, 2003). Finally, from a bending analysis point of view, the outer row does not have soil in front counteracting the soil thrust unlike the inner row. The overall specific unit weight can be calculated by taking into account the volume occupied by the logs and the volume occupied by the soil (Preti and Cantini, 
2002). By following this approach, the overall weight of the log crib wall was calculated as $61.96 \mathrm{kN} / \mathrm{m}$.

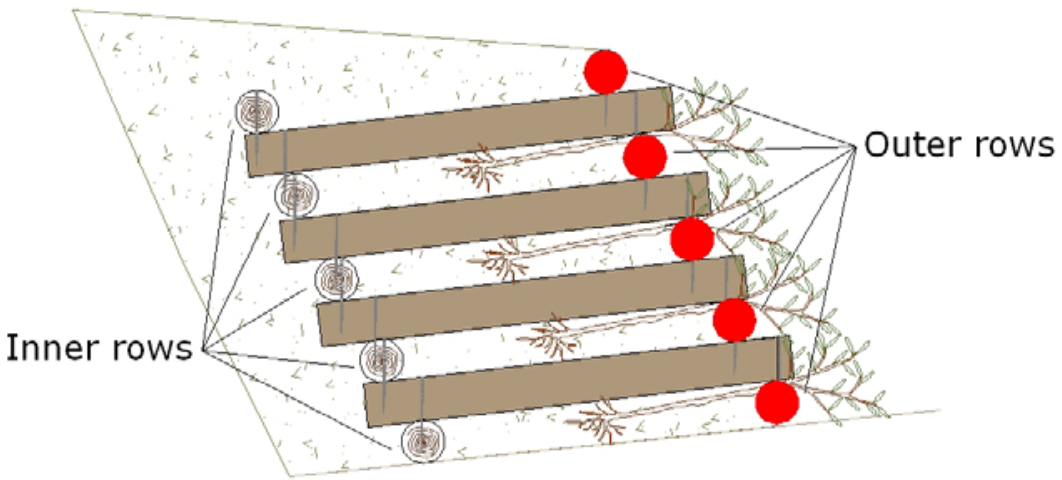

Figure 8 Log crib wall showing natural durability critical situation = in-ground condition (highlighted in red colour).

A minimum maintenance of the living material (willow branches) utilised in the work is assumed to be carried out throughout the work design time scale (i.e. wooden elements service life).

As it is shown in Figure 3, an added cohesion value calculated according to Eq. 6 was used in the sliding stability check. For the overturning stability check case, root pull out force was utilised.

The overall global stability was analysed using stability software (Slope/W 2012, GEO-SLOPE International Ltd, 2014) and spreadsheet (Slip4ex, Greenwood, 2006).

\section{Results}

\subsection{Wood}

The adopted decay model (Leicester et al., 2003) using the input parameters (Section 2.1) shows $r_{\text {corewood }}=2.04 \mathrm{~mm} /$ year, $r_{\text {sapwood }}=8.52 \mathrm{~mm} / \mathrm{yr}, t_{\mathrm{lag}}=0.72 \mathrm{yrs}$, and $\mathrm{L}$ (logs service life) of 6.22 years (Eq. 1, Eq. 2 and Eq. 5; Figure 9). 
Based on the logs service life value ( $L=6.22$ years), and for the purpose of this case study, two additional design stages were defined. One at $t=3$ years (stability check 2.1) and another at $\mathrm{t}=6$ years (stability check 2.2).

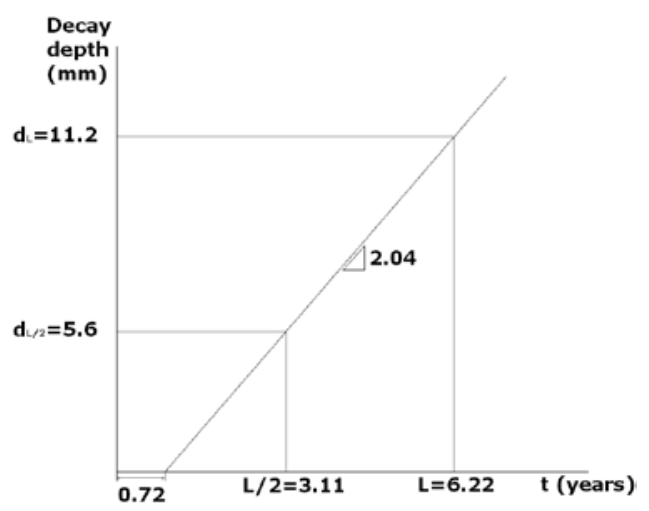

Figure 9 Scots pine idealised decay graph for the study area

\subsection{Plants.}

The five investigated plants showed that the plant resisting pull out force increased with plant age. The maximum pull out force ranged from 1.90 to $3.87 \mathrm{kN}$ for 3 and 6 year old plants respectively. Given that three plants per meter are considered in the wall design (see figure 7), the root pull out values to be used in the overturning stability check will be $5.7 \mathrm{kN}$ and $11.61 \mathrm{kN}$ for t-3 years and t-6 years, respectively.

Since the roots are better developed within the outer half of the log crib wall (Stangl and Tesarz, 2003), the moment arm for the pull-out force is calculated as B/4 (where $B$ is the length of the base of the log crib wall; Figure 7).

The exponential law obtained for the root tensile strength was $T_{r}=28.7981 D^{-}$ $0.87155[\mathrm{MPa}]\left(\mathrm{R}^{2}=0.88\right)$.

For the sliding check, the added cohesion values calculated from Eq. 6 for the selected time scenarios are $4.6 \mathrm{kPa}$ and $5.93 \mathrm{kPa}$ for $\mathrm{t}=3$ years and $\mathrm{t}=6$ years, respectively.

\subsection{Stability}

The external stability checks are shown in the following table 
Table 1 external stability check in the selected time stages $(t=0, t=3$ years and $t=6$ years). Sliding and overturning safety factor formula adapted from Gray and Sotir (1996).

\begin{tabular}{|l|c|c|c|}
\hline & $\begin{array}{c}\mathrm{T}=\text { 0 (long term } \\
\text { check 1; no plant } \\
\text { effects) }\end{array}$ & $\begin{array}{c}\mathrm{T}=\mathbf{3} \text { (long term } \\
\text { check 2.1) }\end{array}$ & $\begin{array}{c}\mathrm{T}=\text { 6 (long term } \\
\text { check 2.2) }\end{array}$ \\
\hline FoS sliding & 1.46 & 1.78 & 1.87 \\
\hline FoS overturning & 2.15 & 2.25 & 2.36 \\
\hline $\begin{array}{l}\text { FoS global (slope } \\
\text { failure check) }\end{array}$ & 1.47 & 1.49 & 1.53 \\
\hline
\end{tabular}

The internal stability checks are shown in the Table 2.

Table 2 Internal stability check in the selected time stages $(t=0, t=3$ years and $t=6$ years). Bending span length equal to $1.6 \mathrm{~m}$. M=design bending moment. R=bending strength according to Eq. 3.

\begin{tabular}{|c|c|c|}
\hline $\begin{array}{c}\text { Check } 1, t=0 \text { years (end of } \\
\text { construction stage) }\end{array}$ & Check 2.1, t=3 years & Check 2.2, $\mathrm{t}=6$ years \\
\hline $\begin{array}{l}\mathrm{M}=6.02 \mathrm{kNm} \\
\text { No decay } \\
\text { Diameter }=0.2 \mathrm{~m} \\
\mathrm{R}=6.05 \mathrm{kNm} \\
\text { Internal stability verified }\end{array}$ & $\begin{array}{l}\mathrm{M}=6.02 \mathrm{kNm} \\
\text { Decay depth }=5.67 \mathrm{~mm} \\
\text { Diameter }=0.18 \mathrm{~m} \\
\mathrm{R}=5.07 \mathrm{kNm} \\
\text { Internal stability } \underline{\text { NOT verified }}\end{array}$ & $\begin{array}{l}\mathrm{M}=6.02 \mathrm{kNm} \\
\text { Decay depth }=11.21 \mathrm{~mm} \\
\text { Diameter }=0.17 \mathrm{~m} \\
\mathrm{R}=4.23 \mathrm{kNm} \\
\text { Internal stability NOT verified. } \\
\text { Wooden elements are not } \\
\text { developing a stabilising effect } \\
\text { any longer. }\end{array}$ \\
\hline
\end{tabular}

\section{Discussion}

The proposed methodology is based on existing engineering standards and, therefore, engineer can become easily familiar with it. In the eco-engineering approach, 
the use of materials which change their properties with time (plants and wood) is very common, and a design methodology making allowance for the deterioration and change of the work will be a very useful tool for eco-engineers. Indeed, the proposed methodology allows the interconnection between the eco-engineering work evolution and the engineering work design stage.

From Table 2 it can be seen that the internal stability is not verified in the check 2.1 ( $\mathrm{t}=3$ years). This would mean that the structure could collapse before the plants had had enough time to develop their reinforcing effect. At this stage, there are two options available: either to increase the log diameter which would involve bringing wood from a different site or to lowering the span of the bending element which would increase the material requirement but will be more sustainable. Choosing the latter case, and a value of $1.45 \mathrm{~m}$ span, would give the values shown in Table 3:

Table 3 Internal stability check with a span of the bending elements equal to $1.45 \mathrm{~m}$.

\begin{tabular}{|l|l|l|}
\hline \multicolumn{1}{|c|}{$\begin{array}{c}\text { Check 1, } \mathbf{t}=\mathbf{0} \text { years (end of } \\
\text { construction stage) }\end{array}$} & \multicolumn{1}{|c|}{ Check 2.1, $\mathbf{t = 3}$ years } & \multicolumn{1}{c|}{ Check 2.2, t = 6 years } \\
\hline $\mathrm{M}=4.95 \mathrm{kNm}$ & $\mathrm{M}=4.95 \mathrm{kNm}$ & $\mathrm{M}=4.95 \mathrm{kNm}$ \\
No decay & Decay depth $=4.79 \mathrm{~mm}$ & Decay depth $=11.21 \mathrm{~mm}$ \\
Diameter $=0.2 \mathrm{~mm}$ & New diameter value $=0.19 \mathrm{~m}$ & New diameter value $=0.17 \mathrm{~m}$ \\
$\mathrm{R}=6.05 \mathrm{kNm}$ & $\mathrm{R}=5.07 \mathrm{kNm}$ & $\mathrm{R}=4.23 \mathrm{kNm}$ \\
Internal stability verified & Internal stability verified & Internal stability NOT verified \\
\hline
\end{tabular}

With this new design, the log crib wall would resist enough time so the vegetation would be able to perform adequately its stabilising role. Therefore, the proposed methodology detected a scenario where the structure would be unstable without giving enough time to the vegetation to properly settle down and reinforce the slope. Traditional design would not have detected this situation and therefore an improvement within the design stage of eco-engineering works has been proven. 
Our analysis shows that the external stability of the bioengineered slope increases with time because of the living plant effects. The sliding safety factor shows the largest increase as also noted in the literature (e.g. Preti and Cantini, 2002). The global safety factor (slope failure check) does not vary much because of the typical shallow root system developed by the goat willow and because of this, the best practice would include basic maintenance (e.g. pruning) to encourage root growth rather than above-ground growth which would further destabilise the slope (Preti and Cantini, 2002). Indeed, with minimum maintenance and treatment tasks plant growth will develop within the wall vertical preventing the generation of eccentric loads which may, in turn, trigger overturning instabilities of the overall structure which is one of the main adverse threats that may ruin the eco-engineering intervention approach (Preti and Cantini, 2002).

The necessary input data for the proposed methodology is either readily available or easily measurable in the field (e.g. Böhm, 1979). The proposed methodology is compatible with theoretical root distribution models such as Laio et al. (2006) or Preti et al. (2010) and can accommodate prediction of the below ground biomass by analysing the above-ground biomass which makes the methodology even more accessible for preliminary design assessment. Similarly, the calculated values of root added cohesion compare well with the published values for willows tested in situ (Norris et al., 2008). However, in order to optimise the design, field data will be necessary and adequate investigations should be undertaken prior to the detailed design stage.

The use of readily available materials (e.g. plants and wood) adjacent to the works site is another feature of the eco-engineering philosophy. The case study presented here showed a very cost effective design when compared to traditional slope stabilisation works. The complexities generated because of both the prioritisation of using available materials and the use of living plants are well managed in the proposed 
methodology. Furthermore, the proposed methodology factors in the change in the material properties of the structural materials and the relative distribution of load transfer between the materials with time, reflecting the live, temporal dimension in the behaviour of the structure which is the novel aspect of the approach. Therefore, a good representation and simulation of eco-engineering works can be embraced within the proposed design method.

As time progresses, both the complete decay of the wooden structure and its collapse will be reached. At this stage, as pointed out by Fernandes and Guiomar (2016), the slope stability will have to be ensured by the autochthonous developed vegetation. The initial rigidity of the eco-engineering work will allow for the triggering of new natural processes such as an improved resilience, an improved ecological functioning, plant communities' succession processes, etc. Hence, the concept of work service life is not clearly applicable to the eco-engineering work case since the final stage of the eco-engineered slope would be represented by a natural ecological evolution of the slope which will include a natural restoration and succession of the indigenous plant communities. Indeed, reaching that natural succession process stage in one of the main aims of the eco-engineering work approach.

Fenandes and Guiomar (2016) analysed the stability of eco-engineering works 20 years after the end of construction stage (once the inert material effects were not present in the slope). Although their work is lacking real case study analyses, they showed for a variety of eco-engineering work types that the autochthonous vegetation stabilising effects were able to maintain and improve the general slope stability. More research is needed for an appropriate description of a complete eco-engineered slope evolution from a design point of view.

The decay values obtained by means of Leicester et al. (2003) model match well with both existing experimental data (Princes Risborough Laboratory, 1976) and the wood mass loss data prediction of the climate data-exposure conditions in Europe 
report (VTT working paper 181, 2011). Indeed, the mass loss predicted in the preceding document in the study area, for exterior above ground wood, is $20 \%$ in a 10 year time span. With Leicester et al. (2003) model, the mass loss obtained for a 10 year period of time is $30 \%$ which is higher than the $20 \%$ predicted in the Climate conditions in Europe report (VTT working paper 181, 2011). This is due to the more critical service life conditions existing in an eco-engineering work (in-ground conditions) and the use of more precise climatic data. Therefore, Leicester et al. (2003) model is worst case and it can be used with more confidence as it will err on the side of safety.

As with other parts of soil mechanics, the methods proposed have to be improved and calibrated with experience because of their semi-empirical nature. The need for adapting and changing our methods according to the new experiences and the analysis of mistakes and failures will refine our accuracy to assess the short and long term behaviour of the eco-engineering techniques and its stabilising effects. This could be accomplished by means of eco-engineering work monitoring tasks. Besides, the collection of experiences of eco-engineering structures (e.g. Stangl, 2007; Böll et al., 2009) in common and shared databases constitutes another remarkable tool at the design stage level.

\section{Conclusions}

The dynamic nature of the eco-engineering works must be incorporated at the design stage in order to realistically simulate and estimate the evolution of the work. Parameters such as wood decay/deterioration processes and the changing living material roles as stabilising factors must be integrated into design methodologies for these types of interventions. A methodology making allowance for the eco-engineering particularities is presented. A time staged design scheme is proposed in order to cover the work evolution within a defined design time scale (the wooden elements service life). The proposed methodology is applied to a real case study incorporating 
measurements and observations on soil as well as the plant root morphology at different time stages. Besides, the methodology follows the sustainability principles such as the use of available materials on or adjacent to the site.

The stress transfer phenomena involved in the typical eco-engineering intervention is well shown in the proposed method. The methodology is able to detect critical design situations unlike traditional engineering design schemes. With the proposed method, the necessary time for the plant to grow and propagate new roots is ensured because, indeed, it is one of the objectives of the design philosophy. With the use of the proposed method both external and internal stability checks with their corresponding safety factor values increase with time and there are no conflicts between the two evolving processes involved in this kind of works which are: the wooden elements deterioration and the living plants evolution with time. An effective combination of these two phenomena is integrated into the design scheme.

The accumulation of eco-engineering monitoring data will be a remarkable source of useful information both to better define the suitable time stages and to gather data regarding wood decay, root morphology and plant evolution.

\section{Acknowledgments}

We would like to thank Mr Alejandro Gómez-Ollauri, PhD candidate, for his invaluable help in the field work. We would also like to thank Dr. José Luis García-Rodriguez for his support and recommendations regarding the pull-out tests.

\section{References}

Bischetti, G. B., Chiaradia, E. A., D'Agostino, V., Simonato, T., 2009. Quantifying the effect of brush layering on slope stability, Ecol. Eng. doi:10.1016/j.ecoleng.2009.03.019

BGS (British Geological Survey). 2013. 1:50 000 Geology [SHAPE geospatial data], Scale 1:50,000, Tiles: sc067, Updated: 1 October 2013. 
Böhm, W., 1979. Methods of studying root systems, Springer Verlag Berlin, pp 275.

Böll, A., Burri, K., Gerber, W., Graf, F., 2009. Long-term studies of joint technical and biological measures. For. Snow Landsc. Res. 82 (1), 9-32.

Boren, H., 1999. Physical and mechanical properties of Finnish thinning wood (Picea abies and Pinus sylvestris). Manuscript of doctoral thesis for University of Joensuu. Faculty of Forestry.

Coutts, M. P., Nielsen, C. C. N., Nicoll, B. C., 1998. The development of symmetry, rigidity and anchorage in the structural root systems of conifers. Plant Soil 217:1-15.

Crook, M. J., Ennos, A. R., 1996. The anchorage mechanics of deep rooted larch, Larix europea $\times$ L. japonica. J Exp Bot 47:1509-1517.

Cucchi, V., Meredieu, C., Stokes, A., Berthier, S., Bert, D., Najar, M., Denis, A., Lastennet, R., 2004. Root anchorage of inner and edge trees in stands of maritime pine (Pinus pinaster Ait.) growing in different podzolic soil conditions. Trees Struc. Funct. 18, 460-466.

Coppin, N. J., Richards, I. J., 1990. Use of Vegetation in Civil Engineering. CIRIA, Butterworths, London.

Duncan, J. M. and Wright, S. G., 2005. Soil strength and slope stability. John Wiley and sons, Inc.

Eaton, R. A. and Hale, M. D. C., 1993. Natural durability. In Wood decay, pests and protection, 1st Edition. Chapman \& Hall, London, pp. 311-318.

Ekanayake, J., Phillips, C., 2002. Slope stability thresholds for vegetated hillslopes: a composite model. Canadian Geotechnical Journal, 39(4):849-862.

EN 384:2010. Structural wood - determination of characteristic values of mechanical properties and density. CEN European Committee for Standardization, Brussels.

EN 1997 - Eurocode 7: Geotechnical design. European Committee for Standardization, Brussels, Belgium, June 2006.

EN 1995-1-1:2004/A1:2008 Eurocode 5: Design of timber structures - Part 1-1: General Common rules and rules for buildings/incl Amendment A1, European Committee for Standardization, Brussels, Belgium, November 2004/2008.

Fernandes, J. P., Guiomar, N., 2016. Simulating the stabilization effect of soil bioengineering interventions in Mediterranean environments using limit equilibrium stability models and 
combinations of plant species. Ecol. Eng. 88, 122-142, http://dx.doi.org/10.1016/j.ecoleng.2015.12.035.

FHWA, 2001. Mechanically Stabilized Earth Walls and Reinforced Soil Slopes: Design and Construction Guidelines, FHWA-NHI-00-43.

Forest Products Laboratory, 1999. Air drying of lumber. Gen. Tech. Rep. FPL-GTR-117. Madison, WI: U.S. Department of Agriculture, Forest Service, Forest Products Laboratory. 62 p. Francis, R. A., Gurnell, A. M., Petts, G. E., Edwards, P. J., 2005. Survival and growth responses of Populus nigra, Salix elaeagnos and Alnus icana cuttings to varying levels of hydric stress. For. Ecol. Manage. 210, 291-301.

GEO-SLOPE International Ltd 2014. Stability modelling with SLOPE/W@_An Engineering Methodology. GEO-SLOPE/W International Ltd., Alberta May 2014 Ed.

González-Ollauri, A., Mickovski, S. B., 2014. Integrated model for the hydro-mechanical effects of vegetation against shallow landslides. EQA-Environmental quality, 13: 37-61. DOI: 10.6092/issn.2281-4485/4535

Gray, D. H. and Leiser, A. T., 1982. Biotechnical Slope Protection and Erosion Control. Van Nostrand Reinhold: New York, N.Y.

Gray, D. H., Sotir, R. B., 1996. Biotechnical and eco-engineering slope stabilization. Wiley, New York, p 276.

Greenwood, J. R., 2006. SLIP4EX- A program for routine slope stability analysis to include the effects of vegetation, reinforcement and hydrological changes. Journal of Geotechnical and Geological Engineering, 24, 3, 449-465. Springer.

Johnson, G. C., Thornton, J. D., Trajstman, A. C. and Cookson, L. J., 2006. Comparative inground natural durability of white and black cypress pines (Callitris glaucophylla and $C$. endlicheri). Australian Forestry 69 (4): 243-247.

Kincardineshire Observer, 2013/4/11. Retrieved on 7/7/2015 from http://www.kincardineshireobserver.co.uk/news/catterline-villagers-pull-together-to-clear-road-12890185

Köppen, W., 1884. The thermal zones of the Earth according to the duration of hot, moderate and cold periods and the impact of heat on the organic world. Meteorol. Z., 1, 215-226. 
Laio, F., D' Odorico, P., Ridolfi, L., 2006. An analytical model to relate the vertical root distribution to climate and soil properties. Geophysical Research Letters, 33:L18401.

Lambe, T. W., Whitman, R. V., 1979. Soil Mechanics, SI version. Wiley \& Sons, New York.

Leicester, R. H., Wang, C-H, Ngyen, M. N., Thornton, J. D., Johnson, G., Gardner, D., Foliente, G. C., MacKenzie, C., 2003. An engineering model for the decay in wood in ground contact. Document No IRGWP 03- 20260. International Research Group on Wood Protection, Stockholm.

Menegazzi, G. and Palmeri, F., 2013. Il dimensionamento delle opera di ingegneria naturalistica. Direzione Infrastrutture, Ambiente e Politiche Abitative. Regione Lazio.

Mickovski, S., Santos, O., Ingunza, P. M. D., Bressani, L., 2015. Coastal slope instability in contrasting geoenvironmental conditions. Proceedings of the XVI ECSMGE Geotechnical Engineering for Infrastructure and Development: 1801-1806. ISBN 978-0-7277-6067-8.

Mickovski, S., 2014. Resilient design of landslip prevention measures: a case study. Proceedings of the ICE - Forensic Engineering 09/2014; DOI: 10.1680/feng.14.00001.

Mickovski, S., Hallet, P., Bransby, M., Davis, M., Sonnenberg, R., Bengough, A., 2009. Mechanical reinforcement of soil by willow roots: impacts of root properties and root failure mechanism. Soil Sci. American Society of Agronomy, 73(4):1276-1285.

Mickovski, S. B., Hallett, P. D., Bengough, A. G., Bransby, M. F., Davies, M. C. R., Sonnenberg, R., 2008. The effect of willow roots on the shear strength of soil. In Advances in GeoEcology 39: The Soils of Tomorrow. Proceedings of the 5th International Congress of the European Society for Soil Conservation, Palermo, Italy, 25-30 June 2007. Edited by C. Dazzi and E. Constantini. Catena Verlag Gmbh, Reiskirchen, Germany. pp. 247-262.

Mickovski, S. B., Van Beek, L. P. H., Salin, F., 2005. Uprooting resistance of vetiver grass (Vetiveria zizanioides). Plant Soil 278:33-41.

Mickovski, S. B. \& Ennos, A. R., 2003. Anchorage and asymmetry in the root system of Pinus peuce. Silva Fennica 37(2): 161-173.

Mickovski, S. B. \& Ennos, A. R., 2002. A morphological and mechanical study of the root systems of suppressed crown Scots pine Pinus sylvestris. Trees (2002) 16:274-280. 
Moore, J., Lyon, A., Searles, G., Lehneke, S., Macdonald, E., 2008. Report on the Investigation of Mechanical Properties of Structural Wood from Three Stands. Strategic Integrated Research in Wood. Scots Pine Wood Quality in North Scotland. Centre for Wood Engineering. Napier University. Edinburgh.

Norris, J. E., 2005. Root reinforcement by hawthorn and oak roots on a highway cut-slope in Southern England. Plant Soil 278:43-53.

Norris, J., Stokes, A., Mickovski, S., Cammeraat, E., van Beek, R., Nicoll, B., et al., 2008. Slope Stability and Erosion Control: Ecotechnological Solutions. Doerdrecht, The Netherlands: Springer.

Preti, F., Cantini, C., 2002. Evoluzione temporale delle condizioni di stabilità per le palificate vive, in Atti XXVIII Convegno di Idraulica e Costruzioni Idrauliche, Potenza, 16-19 settembre, 2002 Provincia di Teramo, Atti Convegno: Opere in grigio, opere in verde.

Preti, F., Dani, A., Laio, F., 2010. Root profile assessment by means of hydrological, pedological and aboveground vegetation information for bio-engineering purposes. Ecological Engineering, 36:305-316.

Princes Risborough Laboratory, 1976. Resultados de los ensayos de durabilidad natural de la madera. AITIM, vol. 78 (marzo/abril).

Ranta-Maunus, A., Saarelainen, U., Boren, H., 1998. Strength of small-diameter round wood. CIB W18 meeting in Savonlinna, Paper 31-6-3. 10 p.

Scheffer, T. C., 1971. A climate index for estimating potential for decay in wood structures above ground. Forest Products Journal, 21(10), 25-31.

Schenk, H. J., Jackson, R. B., 2002. Rooting depths, lateral root spreads and belowground/above-ground allometries of plants in water-limited ecosystems. J. Ecol. 90, 480-494.

Schiechtl, H. M., 1988. Hangsicherungen mit ingenieurbiologischen Methoden im Alpenraum. Erosionbeckämpfung im Hochgebirge. Jahrb. Ges. Ingenieurbiol., 3: 50-77.

Simpson, W. T., Wang, X., 2001. Relationship between longitudinal stress wave transit time and moisture content of lumber during kiln drying. Forest Products Journal 51(10):51-54.

Sowers, G. F., 1979. Introductory Soil Mechanics and Foundations: Geotechnical Engineering. 4th ed., Macmillan, New York. 
Stangl, R., 2007. Hedge Brush Layers and Live Crib Walls-stand Development and Benefits. Springer: Dordrecht.

Stangl, R., Tesarz M., 2003. Wirksamkeit von bepflanzten Holzkrainerwänden als ingenieurbiologische Hangsicherungsmassnahmen - Universität für Bodenkultur - Wien.

State Forests of New South Wales, 1995. Wood for external uses. Technical Publication. Research Division. Series number 6. ISSN 0155-7548 ISBN: 073102206 8. ISSN: 0155-7548. ISBN: 0731022068.

Stokes, A., Douglas, G., Fourcaud, T., Giadrossich, F., Gillies, C., Hubble, T., et al., 2014. Ecological mitigation of hillslope instability: ten key issues facing researchers and practitioners. Plant Soil, 377:1-23.

Stokes, A., Ghani, M. A., Salin, F., Danjon, F., Jeannin, H., Berthier, S., Kokutse, A. D., Frochot, H., 2007. Root morphology and strain distribution during tree failure on mountain slopes. In: Stokes, A., Spanos, I., Norris, J. E. \& Cammeraat, E. (Eds.). Eco-and Ground Bio-Engineering: The Use of Vegetation to Improve Slope Stability: Proceedings of the first International Conference on Eco-engineering 13-17 September 2004 (pp. 165-173). Dordrecht, The Netherlands: Springer.

Stokes, A., Norris, J., van Beek, L., Bogaard, T., Cammeraat, E., Mickovski, S., et al., 2008. How vegetation reinforces soil on slopes. In J. Norris, A. Stokes, S. Mickovski, E. Cammeraat, R. Van Beek, B. Nicoll, et al., Slope Stability and Erosion Control: Ecotechnological Solutions (pp. 65-116). Dordrecht, The Netherlands: Springer.

Tardio, G. and Mickovski, S. B., 2015. Method for synchronisation of soil and root behaviour for assessment of stability of vegetated slopes. Journal of ecological engineering 82:222:230. http://dx.doi.org/10.1016/j.ecoleng.2015.04.101.

Terzaghi, K. V., 1936. Stability of slopes of natural clay. Proceedings of the First International Conference on Soil Mechanics and Foundation Engineering. Cambridge, MA, Vol. 1, pp. 161165.

UK Met Office. MIDAS Land Surface Stations Data, 1853-current. Retrieved from http://badc.nerc.ac.uk/view/badc.nerc.ac.uk_ATOM_dataent_ukmo-midas 
Van Noordwijk, M., Brouwer, G., Meijbroom, F., Oliveira, M. R. G., Bengough, A. G., 2000. Trench profile techniques and core break methods. In AL Smit (ed), Root methods: A handbook. Springer, Berlin, pp 211-233.

Vries, de P. A., 1998. Quality and strength characterisation of small diameter Larch (Larix kaempferi (LMAB.) CARRR.). Report C4-98-01, Delft University, Delft/Netherlands.

VTT working paper 181, 2011. Climate data-exposure conditions in Europe. URL: http://www.vtt.fi/publications/index.jsp

Waisel, Y., Eshel, A., Kafkafy, U., 2002. Plant Roots: The Hidden Half, 3rd edition. Mercel Dekker Inc., New York.

Waldron, L. J., Dakessian, S., 1981. Soil reinforcement by roots: calculation of increased soil resistance from root properties. Soil Science 132(6): 427-35.

Waldron, L. J., 1977. The shear resistance of root permeated homogeneous and stratified soil. J Soil Sci Soc Am 41:843-849.

Wang, C. H., Leicester, R. H., Foliente, G. C., Nguyen, M. N., 2007. Wood service life design guide. Forest and Wood Products Australia Limited.115 pp.

Willat, S. T., Sulistyaningsih, N., 1990. Effect of plant roots on soil strength. Soil Till Res 16:329336.

Willeitner, H. and Peek, R. D., 1997. The natural durability story. International Research Group on Wood Preservation, Stockholm.IRG Doc. IGR/WP 97-20119.

Wu, H., Mckinnell, W., Swanston, D., 1979. Strength of tree roots and landslides on Prince of Wales Island, Alaska. Canadian Geotechnical Journal, 16(1):19-33.

Zeh, H., 2007. Ingenieurbiologie. Handbuch Bautypen. p. 448, Zürich: Europäische Föderation für Ingenieurbiologie, Verein für Ingenieurbiologie.

Zobel, B. J. and Sprague, J. R., 1998. Juvenile Wood in Forest Trees. Springer-Verlag, Berlin, Germany. 